\title{
FAKTOR-FAKTOR YANG MEMENGARUHI MINAT BELI PANGAN ORGANIK MELALUI SITUS ONLINE
}

\author{
Hasrini Sari ${ }^{* 1}$ dan Aditya Parama Setiaboedhi ${ }^{*}$ \\ *) Program Studi Teknik Industri dan Manajemen Rekayasa Industri, Fakultas Teknologi Industri, \\ Institut Teknologi Bandung \\ Gedung Laboratorium Teknologi III, Jl. Ganesha 10, Bandung 40132
}

\begin{abstract}
This study is aimed to explore the factors that can increase the intention to buy and their implications in the design of marketing sites. Theoretical background used in the study is mainly adopted from the Technology Acceptance Model. Five variables are included in this research including Online Buying Intention, Ease of Use, Perceived Usefulness, Trust and Information on the Site. Data of 426 respondents were collected and analyzed using statistical methods of structural equation modeling to test the research model. The results show that the Information on the Site significantly influences Trust, and Perceived Usefulness and Trust significantly influence Online Buying Intention. Ease of Use does not significantly influence Online Buying Intention. The results of this study later become the basis for designing the information presented on a site of organic processed foods in a form of recommendations on information that should be presented on its website.
\end{abstract}

Keywords: technology acceptance model, online marketing, websites, organic products, structural equation modelling

\begin{abstract}
ABSTRAK
Penelitian ini bertujuan menggali faktor-faktor yang dapat meningkatkan minat beli dari pengunjung situs, serta implikasinya dalam perancangan situs pemasaran, Model utama mengadopsi Technology Acceptance Model. Empat variabel digunakan dalam penelitian ini, yaitu kemudahan penggunaan, persepsi terhadap kegunaan, rasa percaya dan informasi pada situs. Data untuk menguji model penelitian dikumpulkan dari 426 responden, dan dianalisis menggunakan metode statistik structural equation modelling. Hasilnya menunjukkan bahwa informasi pada situs berpengaruh signifikan terhadap rasa percaya. Persepsi terhadap kegunaan dan rasa percaya berpengaruh signifikan terhadap minat beli online. Kemudahan penggunaan tidak berpengaruh signifikan terhadap minat beli online. Hasil penelitian ini kemudian menjadi dasar dalam merancang informasi yang disajikan pada sebuah situs makanan olahan organik, yaitu dengan merekomendasikan informasi-informasi yang sebaiknya ditampilkan pada situs.
\end{abstract}

Kata kunci: technology acceptance model, pemasaran online, situs, produk organik, structural equation modelling

\footnotetext{
${ }^{1}$ Alamat Korespondensi:

Email: hasrinis@gmail.com
}

\section{PENDAHULUAN}

Pasar pangan organik di dunia memiliki kecenderungan mengalami peningkatan. Meskipun demikian, produk pertanian organik belum merupakan suatu bisnis yang besar, tetapi dari tahun ke tahun menunjukan peningkatan yang signifikan. Jika pada tahun 1997 pasar pangan organik baru sekitar USD10 Milyar; maka pasar tersebut mencapai sekitar USD72 Milyar pada tahun 2013 (IFOAM, 2015). Sementara itu, permintaan dunia terhadap produk pertanian organik mengalami pertumbuhan sekitar $20 \%$ per tahun (Idaman et al. 2012). Di Indonesia sendiri, program pertanian organik didukung oleh pemerintah, salah satunya dengan penyusunan standar sistem pertanian organik (Muzayanah et al. 2015). Namun demikian, pangsa pasar pangan organik di Indonesia hanya tumbuh sekitar 5\% per tahun, dengan nilai penjualan sekitar Rp10 Milyar (Handriana, 2014). 
Hal ini disebabkan karena produk organik memiliki ciri khas tersendiri yang merupakan tantangan dalam memasarkan produk. Dua faktor utama yang sangat melemahkan posisi produk organik dibandingkan dengan produk nonorganik adalah kurangnya manfaat yang segera dan harga. Manfaat produk organik, seperti efek pada kesehatan dan lingkungan, tidak dicapai atau segera dirasakan oleh pelanggan setelah konsumsi. Manfaat hanya menjadi efektif setelah beberapa waktu, dan disebut sebagai manfaat intangible.

Selain itu, produk organik pada umumnya mengenakan harga yang lebih tinggi dari pesaing nonorganik karena biaya bahan baku yang lebih tinggi dan/atau proses yang lebih rumit. Kombinasi harga yang lebih mahal dan manfaat intangible menempatkan produk organik ke posisi lebih rendah dibandingkan dengan produk nonorganik dalam proses pengambilan keputusan pembelian oleh pelanggan (Sari dan Firmanzah, 2011).

Pemasaran menjadi kunci dalam meningkatkan konsumsi produk organik di Indonesia. Di lain pihak, para pelaku bisnis produk organik di Indonesia sebagian besar adalah Usaha Kecil Menengah (UKM) sehingga mereka memiliki sumber daya keuangan terbatas untuk melakukan kegiatan pemasaran. Oleh karena itu, para produsen makanan organik membutuhkan jenis program pemasaran yang dapat dijalankan dengan biaya rendah namun dapat menjangkau khalayak yang banyak dan sesuai dengan target. Pemasaran online, yaitu pemasaran yang memanfaatkan internet, memenuhi persyaratan ini. Pemasaran online memiliki keuntungan membutuhkan biaya investasi yang relatif rendah, mudah digunakan, cakupan jaringan yang luas, penyebaran dan pengumpulan informasi cepat serta mudah mencari mitra bisnis potensial. Muzayanah et al. (2015) mengemukakan bahwa sumber informasi utama mengenai pangan organik berasal dari internet.

Salah satu media pemasaran online yang dapat digunakan adalah situs. Situs merupakan sarana pemasaran yang tepat bagi produk organik karena dapat memberikan banyak informasi pada para pengunjungnya. Menurut Muzayanah et al. (2015), kendala dalam pemasaran pangan organik salah satunya adalah keterbatasan informasi mengenai produk tersebut. Namun demikian, situs membutuhkan perencanaan dan desain yang baik untuk dapat mendorong peningkatan pemasaran. Berbeda dari pemasaran yang tidak berbasis internet (offline), situs adalah satu-satunya hal yang mewakili perusahaan di mata pengunjung. Oleh karena itu, tampilan situs dan informasi yang disediakan didalamnya akan sangat penting dalam rangka meningkatkan niat untuk membeli pengunjung. Salah satu produsen makanan olahan organik di Indonesia meluncurkan situs sebagai sarana untuk menjual produknya. Namun, setelah delapan bulan hanya menghasilkan penjualan satu kali saja.

Masalah yang dihadapi oleh para pelaku industri kecil pada umumnya dan produsen pangan organik pada khususnya dalam mengoptimalkan penggunaan pemasaran online seperti yang telah dipaparkan di atas menjadi latar belakang penelitian ini. Untuk itu, studi terhadap penelitian terdahulu mengenai pemasaran online dilakukan. Model dasar yang digunakan adalah Technology Acceptance Model (TAM).

Technology Acceptance Model (TAM) dikembangkan oleh Davis (1989) kemudian disempurnakan oleh Davis, Bagozzi dan Warshaw (1989). Model ini kemudian berkembang menjadi model yang paling banyak diterapkan untuk mengukur penerimaan pelanggan terhadap suatu produk (Venkatesh, 2000). Model ini terbukti adalah model yang baik dalam memprediksi penerimaan pelanggan terhadap teknologi informasi (Gefen, 2003). Model dasar dari TAM sendiri adalah Theory of Reasoned Action (Ajzen dan Fishbein 1980; Fishbein dan Ajzen, 1975 dalam Solomon, 2007).

Model TAM menyatakan bahwa minat seorang pelanggan untuk menggunakan suatu teknologi tergantung pada dua kepercayaan (belief), yaitu persepsi terhadap kemudahan penggunaan (Perceived Ease of use, PEOU) dan persepsi terhadap manfaat produk tersebut (Perceived Usefulness, PU). Persepsi terhadap manfaat produk pun dipengaruhi oleh persepsi terhadap kemudahan penggunaan produk karena semakin mudah suatu teknologi digunakan, semakin bermanfaat teknologi tersebut (Davis, 1989). Pada awalnya, sikap terhadap teknologi memediasi hubungan antara dua kepercayaan dengan intensi (Davis, 1989). Namun, pada model terakhir variabel ini dihilangkan karena adanya hubungan yang sangat kuat antara persepsi terhadap manfaat dengan intensi. Sementara itu, hubungan persepsi manfaat terhadap sikap sendiri lemah. Jadi, pelanggan akan tetap memiliki keinginan untuk menggunakan suatu teknologi karena bermanfaat meskipun tidak memiliki afeksi yang positif terhadap perilaku tersebut. Model terakhir dari TAM sudah 
teruji secara empiris melalui proses validasi, aplikasi dan replikasi oleh banyak peneliti menurut Venkatesh (2000) serta telah diuji pula oleh Gefen (2003); Gefen et al. (2003); serta Kaplan et al. (2007).

Wu dan $\mathrm{Ke}$ (2015) dalam studi meta analisisnya mengintegrasikan karakteristik kepribadian, technology acceptance dan persepsi terhadap resiko dalam memengaruhi perilaku pembelian online. Studi tersebut menunjukkan bahwa persepsi terhadap kemudahan penggunaan dan persepsi terhadap kegunaan memengaruhi minat beli online.

Aren et al. (2013) mengadopsi model TAM dalam penelitiannya dan menambahkan satu variabel rasa percaya, sebagai variabel independen yang memengaruhi variabel dependen minat beli kembali. Di samping itu, pada penelitian tersebut ditambahkan variabel dependen kegembiraan (enjoyment). Selanjutnya, Hong-You et al. (2016) dalam studinya menemukan pengaruh signifikan dari persepsi terhadap informasi yang diperoleh dari jejaring sosial terhadap perilaku online dengan dimediasi oleh rasa percaya. Ponte et al. (2015) dalam penelitiannya menggunakan variabel kualitas informasi sebagai salah satu anteseden dari rasa percaya.

Erkan dan Evans (2016) mengembangkan model yang menghubungkan secara tidak langsung kualitas informasi sebagai salah satu variabel penelitiannya, dengan minat beli pada konteks iklan di media sosial. Hasil penelitian tersebut menunjukkan bahwa kualitas informasi berpengaruh signifikan terhadap minat beli dengan dimediasi oleh persepsi terhadap kegunaan informasi dan adopsi informasi.

Variabel yang berkaitan dengan informasi kemudian diadopsi untuk mengetahui pengaruh dari paparan informasi yang disampaikan pada situs terhadap rasa percaya dan minat beli pelanggan. Variabel ini menjadi penting dalam konteks produk organik. Hal ini untuk mengatasi salah satu kendala pemasaran produk organik yaitu keterbatasan informasi (Muzayanah et al. 2015). Pada penelitian ini, variabel tersebut dinamakan informasi pada situs.

Variabel-variabel yang digunakan dalam penelitian ini adalah variabel rasa percaya, kemudahan penggunaan (ease of use), dan persepsi terhadap kegunaan (perceived usefulness), kualitas informasi pada situs (information quality) dan minat beli online (online shopping intention). Jadi, model penelitian yang digunakan di sini berbeda dengan penelitian-penelitian sebelumnya yang menggunakan model dasar TAM karena menambahkan variabel Informasi pada Situs sebagai salah satu variabel independen yang memengaruhi minat beli dengan dimediasi oleh Rasa Percaya. Penelitian terdahulu sebagai dasar dari model penelitian ini antara lain Davis et al. (1989) dengan variabel penelitian kemudahan penggunaan (perceived ease of use), dan perceived usefulness (PU), memengaruhi minat menggunakan teknologi. Aren et al. (2013) menggunakan kemudahan penggunaan (perceived ease of use), persepsi terhadap kegunaan (perceived usefulness) dan rasa percaya, (trust), memengaruhi minat membeli kembali dan kegembiraan (enjoyment) sebagai variabel penelitian. Selanjutnya, Ponte et al. (2015) menggunakan variabel rasa percaya dan persepsi terhadap nilai memengaruhi minat beli; rasa percaya dipengaruhi oleh perceived security, perceived privacy dan information quality; persepsi terhadap nilai dipengaruhi oleh rasa percaya. Pada penelitian ini, penulis menggunakan minat beli dipengaruhi oleh rasa percaya, kemudahan penggunaan (ease of use), dan persepsi terhadap kegunaan (perceived usefulness); rasa percaya dipengaruhi oleh Informasi pada situs sebagai variabel penelitian. Jadi, penelitian ini bertujuan menggali faktor-faktor yang dapat meningkatkan minat beli dari pengunjung situs, serta implikasinya dalam perancangan situs pemasaran, khususnya produk makanan olahan organik.

\section{METODE PENELITIAN}

Output dari studi ini adalah hal-hal yang perlu diperhatikan dalam perancangan situs pemasaran untuk produk organik yang dapat meningkatkan minat beli dari pengunjung. Untuk itu, dilakukan penelitian yang terdiri dari dua tahap, pada tahap pertama, dilakukan identifikasi faktor-faktor yang memengaruhi minat beli online. Pada tahap ini, dilakukan penelitian dengan menggunakan metode riset kuantitatif, yaitu suatu metode penelitian yang dilakukan untuk menguji teoriteori tertentu melalui pengujian terhadap hubungan antar variabel dengan menggunakan instrumen penelitian (Creswell, 2016). Obyek penelitian pada tahap pertama ini adalah situs yang sering dikunjungi oleh para responden tersebut. Responden yang dituju adalah mereka yang sudah sering menggunakan internet, dan haruslah orang yang pernah melakukan pembelian online setidaknya satu kali. Data primer yang dibutuhkan dalam penelitian ini diperoleh melalui 
metode survei dengan bantuan instrumen pengukuran berupa kuesioner online dan tertulis. Kuesioner terdiri dari dua bagian, bagian pertama ditujukan untuk mengetahui profil responden. Bagian kedua berisi pertanyaan-pertanyaan yang berkaitan dengan model penelitian. Kuesioner online dibuat dalam Googleform dengan tautan. Tautan tersebut disebarkan melalui media sosial dan yang paling banyak digunakan adalah LINE dan Facebook. Alasan penggunaan kuesioner online sebagai media pengumpulan data utama adalah karena diasumsikan bahwa konsumen yang pernah melakukan pembelian melalui internet sudah mengenal kuesioner yang disebar menggunakan form online.

Pengumpulan data melalui kuesioner tertulis juga dilakukan, dengan strukur pertanyaan yang sama dengan kuesioner online. Kuesioner tertulis disebarkan di sekitar jalan Ganesha dan beberapa perkantoran di Kota Bandung. Penyebaran kuesioner online dan offline dilakukan sekitar bulan Juni-Agustus 2015.

Variabel-variabel yang digunakan dalam penelitian ini adalah variabel kemudahan penggunaan (ease of use), dan persepsi terhadap kegunaan (perceived usefulness) serta informasi pada situs sebagai variabel independen. Variabel dependen pada penelitian ini adalah rasa percaya dan minat beli online. Instrumen pengukuran dari masing-masing variabel menggunakan skala pengukuran semantic differential $(1$ = Sangat Tidak Setuju, sampai dengan 7 = Sangat Setuju). Kemudahan penggunaan diukur oleh 4 indikator, persepsi terhadap kegunaan situs diukur oleh 3 indikator, informasi pada situs diukur oleh 3 indikator, rasa percaya diukur oleh 4 indikator. Sementara itu, minat beli secara online diukur oleh 4 indikator. Rincian dari indikator masingmasing variabel dapat dilihat pada Tabel 1 .

Metode sampling yang digunakan adalah sampling nonprobabilitas judgment sampling, yaitu pemilihan sampel oleh peneliti berdasarkan karakteristik tertentu sesuai dengan tujuan penelitian (Zikmund, 2000). Karakteristik yang dipilih adalah orang-orang yang sudah pernah melakukan pembelian secara online minimal satukali. Jumlah minimum sampel yang diambil mengacu pada Hair et al. (2010), yang menyatakan bahwa jumlah sampel yang diambil minimal lima kali dari jumlah parameter yang dianalisis, dan akan lebih memuaskan apabila sepuluh kalinya. Aturan umum berlaku untuk teknik analisis multivariat secara umum, tidak mengacu spesifik kepada teknik multivariat tertentu. Penelitian ini menggunakan 18 parameter yang berupa pertanyaan-pertanyaan dalam kuesioner, sehingga jumlah sampel minimal yang diambil adalah sebesar $18 \times 10=180$ sampel dengan menggunakan perbandingan jumlah sampel dengan parameter sama dengan 10:1. Data dari kuesioner kemudian diolah

Tabel 1. Indikator variabel studi

\begin{tabular}{|c|c|}
\hline Variabel & Indikator \\
\hline $\begin{array}{l}\text { Rasa percaya (TR): keyakinan subjektif bahwa } \\
\text { penjual online akan memenuhi kewajiban } \\
\text { transaksi sebagaimana yang dipahami oleh } \\
\text { pelanggan }\end{array}$ & $\begin{array}{l}\text { - Kepercayaan terhadap informasi yang disediakan situs (TR1) } \\
\text { - Kepercayaan terhadap janji yang disampaikan pada situs (TR2) } \\
\text { - Kepercayaan terhadap produk yang disediakan situs (TR3) } \\
\text { - Kepercayaan terhadap jasa pengiriman yang dipakai (TR4) }\end{array}$ \\
\hline $\begin{array}{l}\text { Informasi pada situs (WI): persepsi pelanggan } \\
\text { terhadap akurasi dari informasi yang disajikan } \\
\text { pada situs mengenai produk yang ditawarkan dan } \\
\text { prosedur untuk melaksanakan transaksi pembelian } \\
\text { secara online }\end{array}$ & $\begin{array}{l}\text { - Informasi yang akurat mengenai produk (WI1) } \\
\text { - Informasi yang memadai ketika ingin melakukan transaksi (WI2) } \\
\text { - Informasi yang terkini (WI3) }\end{array}$ \\
\hline $\begin{array}{l}\text { Kemudahan penggunaan (EOU): tingkat } \\
\text { kepercayaan individu terhadap suatu teknologi, } \\
\text { bahwa teknologi tersebut dapat memudahkan } \\
\text { dirinya dalam bekerja atau menghindarkan dari } \\
\text { usaha yang besar }\end{array}$ & $\begin{array}{l}\text { - Kemudahan menggunakan situs (EOU1) } \\
\text { - Upaya yang dibutuhkan untuk mengoperasikan situs (EOU2) } \\
\text { - Kemudahan untuk melakukan pemesanan (EOU3) } \\
\text { - Orang yang pertama kali membeli dapat melakukan pembelian } \\
\text { tanpa membutuhkan banyak bantuan (EOU4) }\end{array}$ \\
\hline $\begin{array}{l}\text { Persepsi terhadap kegunaan situs (PU): tingkat } \\
\text { kepercayaan individu terhadap kemampuan suatu } \\
\text { teknologi dalam meningkatkan kinerja }\end{array}$ & $\begin{array}{l}\text { - Berguna dalam membeli apa yang diinginkan (PU1) } \\
\text { - Membuat hidup lebih mudah (PU2) } \\
\text { - Memudahkan untuk berbelanja (PU3) }\end{array}$ \\
\hline $\begin{array}{l}\text { Minat beli secara online (OPI): tingkat } \\
\text { kecenderungan pelanggan untuk melakukan } \\
\text { pembelian produk situs }\end{array}$ & $\begin{array}{l}\text { - Probabilitas mempertimbangkan untuk membeli produk dari situs } \\
\text { (OPI1) } \\
\text { - Kemungkinan untuk membeli produk dari situs (OPI2) } \\
\text { - Kesediaan untuk membeli produk dari situs (OPI3) } \\
\text { - Jika ingin membeli produk tertentu, akan mempertimbangkan untuk } \\
\text { membelinya dari situs (OPI4) }\end{array}$ \\
\hline
\end{tabular}


dengan menggunakan metode analisis kuantitatif, yaitu analisis statistik deskriptif dan inferensial.

Analisis statistik deskriptif terutama digunakan untuk mengolah data profil responden dan jawaban responden untuk setiap item pengukuran. Ukuran statistik yang digunakan adalah rata-rata, frekuensi, dan standar deviasi. Statistik inferensial digunakan untuk menguji kemampuan model penelitian dalam menjelaskan fenomena minat beli online dengan metode Structural Equation Modelling (SEM) menggunakan program LISREL 9.2. Metode ini dipilih agar dapat melihat pengaruh dari setiap variabel secara simultan.

Tahap berikutnya adalah merancang situs pemasaran online yang sesuai untuk pasar pembeli online dengan memperhatikan hasil penelitian tahap sebelumnya. Agar lebih fokus, penelitian ini memilih situs dari produsen makanan olahan organik sebagai objek studi. Produsen tersebut menjual makanan dari bahan-bahan organik, dan tidak menggunakan bahan pengawet atau aditif. Situs ini sudah diluncurkan selama delapan bulan namun hanya menghasilkan penjualan satu kali. Kerangka penelitian ini dalam bentuk bagan alur penelitian dapat dilihat pada Gambar 1.

Model penelitian (Gambar 2) dan hipotesis penelitian ini adalah sebagai berikut:
H1 : Informasi pada situs berpengaruh positif terhadap rasa percaya

H2 : Rasa percaya berpengaruh positif terhadap minat beli online

H3 : Persepsi terhadap kemudahan penggunaan berpengaruh positif terhadap minat beli online

H4 : Persepsi terhadap kegunaan berpengaruh positif terhadap minat beli online

\section{HASIL}

Pengolahan data awal dilakukan untuk mendeteksi adanya data yang menyimpang (outliers) dan data yang hilang (missing values). Hasil analisis statistik menunjukkan bahwa tidak perlu dilakukan penanggulangan terhadap kedua hal tersebut. Data yang terkumpul 466 buah, dan yang valid sebanyak 426 buah. Hasil pengolahan data terhadap profil responden menunjukkan bahwa $64,8 \%$ wanita, $62,3 \%$ berusia antara 18-23 tahun, 45,8\% pendidikan terakhir SMA dan sederajat, $67,6 \%$ pelajar, $69,7 \%$ berbelanja online pada waktu-waktu tertentu saja, $44,7 \%$ mengeluarkan Rp100.000-300.000 untuk transaksi pembelian online selama satu bulan terakhir, $37,8 \%$ berbelanja online melalui media sosial atau $32,9 \%$ melalui toko online bisnis ke konsumen, $82,9 \%$ membayar melalui transfer

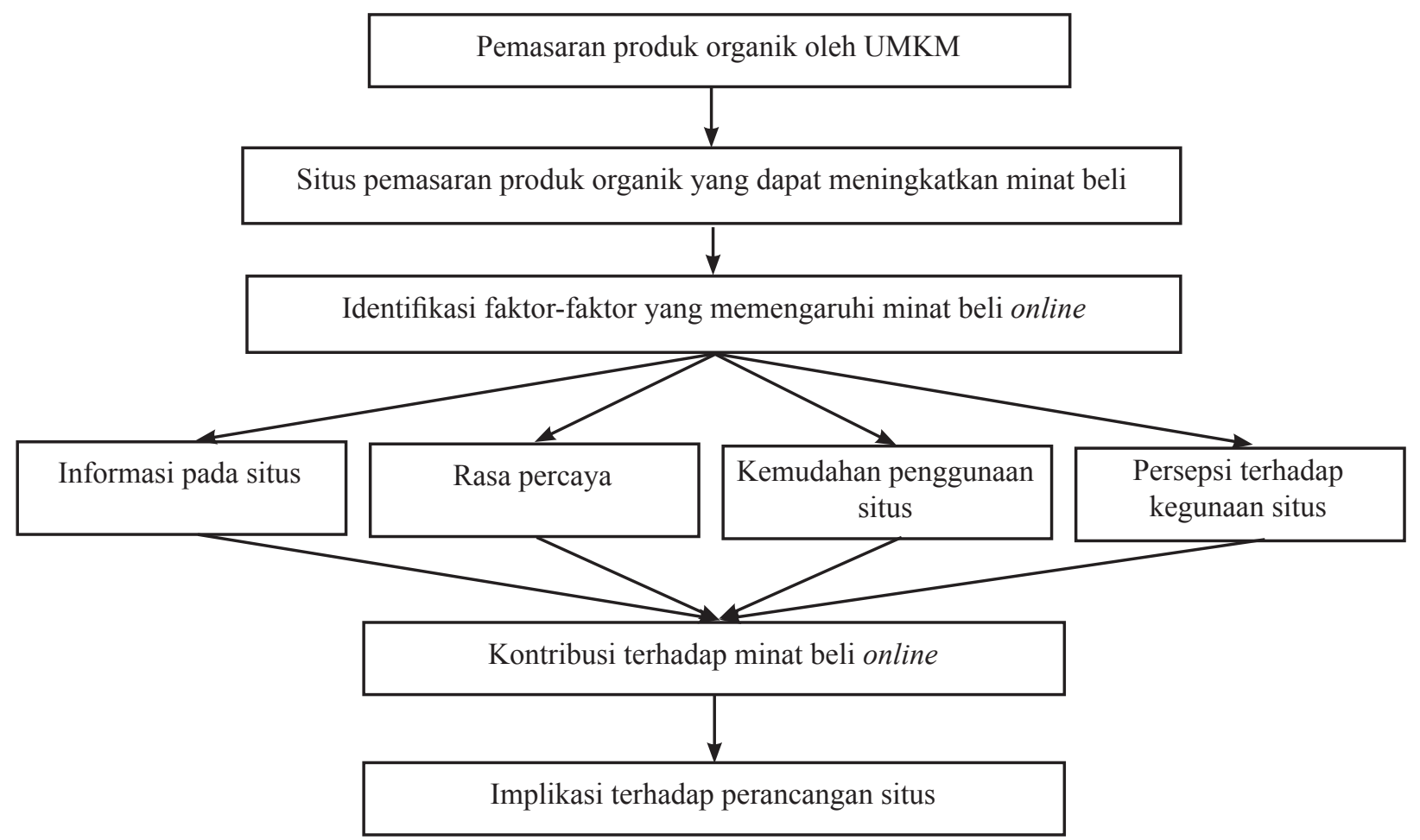

Gambar 1. Kerangka pemikiran penelitian 


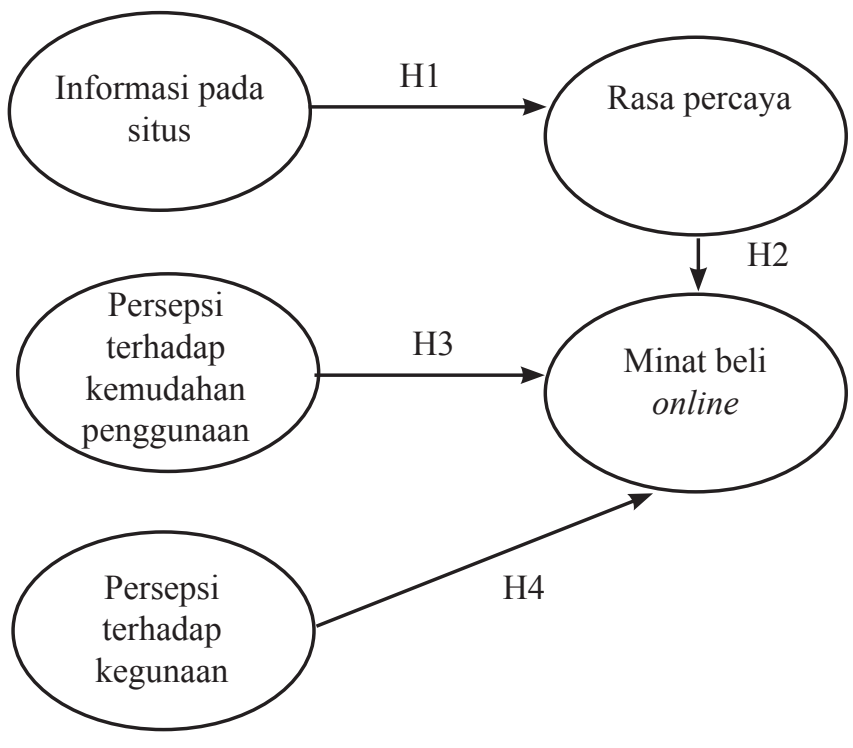

Gambar 2. Model penelitian

bank, dan $25,1 \%$ pernah membeli produk organik dan sebagian besar membelinya di toko swalayan.

Ditinjau dari usia, maka sebagian besar responden termasuk dalam Generasi Y, yaitu kelompok generasi yang lahir antara tahun 1980-2000. Karakteristik dari generasi ini antara lain adalah pada umumnya memiliki daya beli yang tinggi, sudah mengenal internet sejak usia dini, dan menggunakan internet dalam kehidupan sehari-hari seperti membuat blog, memesan tiket perjalanan, perbankan, mencari informasi, dan lain-lain (Petra, 2016). Oleh karena itu, kelompok responden merupakan calon pelanggan potensial untuk pemasaran berbasis online. Meskipun demikian, faktor demografis tidak berpengaruh signifikan dalam keputusan pembelian online seperti hasil penelitian Khare (2016), namun pemasaran online yang ditujukan pada kelompok pelanggan yang sudah melek internet tentu akan lebih mudah.

Hasil analisis statistik deskriptif menunjukkan bahwa item "informasi pada situs yang terpercaya" memiliki rata-rata tertinggi, yaitu 6,42 (standar deviasi 0,91). Artinya, kepercayaan terhadap informasi yang disampaikan pada situs menjadi faktor yang paling dipertimbangkan responden dalam melakukan pembelanjaan online. Sementara item pengukuran "berbelanja online dapat memenuhi kebutuhan" memiliki rata-rata terendah yaitu 4,85 (standar deviasi 1,48). Artinya responden memandang bahwa kegunaan dalam memenuhi kebutuhan bukanlah faktor utama yang dipertimbangkan dalam berbelanja online. Hasil selengkapnya dari statistik deskriptif dapat dilihat pada Tabel 2.
Output dari analisis statistik multivariat menunjukkan, yaitu nilai RMSEA 0,046, CFI 0,98, GFI 0,96, RMR 0,047 sehingga dapat disimpulkan bahwa model memenuhi kriteria minimal bagi kecocokan absolut, yaitu nilai RMSEA kurang dari 0,1; GFI dan CFI lebih dari 0,8 serta RMR kurang atau sama dengan 0,05 (Wijayanto, 2008). Nilai CN 349,7 menunjukkan bahwa model memenuhi kriteria minimum 200 (Wijayanto, 2008) sehingga cukup mewakili sampel data. Untuk uji validitas, semua nilai absolut t lebih besar atau sama dengan dua dan standardized loading factor lebih dari 0,5. Wijayanto (2008) dan Hair et al. (2010) menyatakan bahwa kriteria minimal factor loading yang masih dapat diterima adalah 0,5 . Oleh karena itu, enam indikator tidak diikutsertakan pada pengolahan data selanjutnya, yaitu TR4, OPI4, WI3, EOU2, PU1. Loading factor dari masing-masing indikator yang nilainya lebih dari 0,5 dapat dilihat pada Tabel 3. Hasil perhitungan uji reliabilitas menunjukkan bahwa reliabilitas konstruk sebesar 0,91 dan variance extracted 0,6.

Dari kedua indikator ini dapat disimpulkan bahwa reliabilitas model adalah baik. Untuk persamaan struktural, semua koefisien menunjukkan nilai signifikansi yang lebih dari 2, kecuali koefisien kemudahan penggunaan terhadap minat beli online. Nilai dari Adjusted $\mathrm{R}^{2}$ sebesar 0,919 untuk hubungan antara rasa percaya dan informasi pada situs adalah sangat baik. Sementara itu, untuk persamaan yang menunjukkan hubungan antara minat beli online dengan rasa percaya, kemudahan penggunaan dan Persepsi terhadap kegunaan situs nilai $\mathrm{R}^{2}$ sebesar 0,376 adalah cukup (Wijayanto, 2008). Koefisien determinasi $\left(\mathrm{R}^{2}\right)$ menunjukkan besarnya penggaruh dari variabelvariabel independen dalam model ini terhadap variabel dependen, sedangkan sisanya diberikan oleh variabel bebas di luar model penelitian. Output dari SEM dapat dilihat pada Gambar 3 dan 4.

Persamaan multivariat yang diperoleh adalah sebagai berikut:

$$
\begin{gathered}
\mathrm{TR}=0,895 * \mathrm{WI} \\
\mathrm{OPI}=0,245 * \mathrm{TR}+0,503 * \mathrm{PU}
\end{gathered}
$$

Keterangan:
TR : Rasa percaya
WI : Informasi pada situs
EOU : Kemudahan penggunaan 


\section{PU : Persepsi terhadap kegunaan}

Hasil penelitian ini menunjukkan bahwa rasa percaya dipengaruhi oleh informasi yang disajikan oleh situs (H1 terbukti), sesuai dengan hasil penelitian Ponte et al. (2015). Minat beli online dipengaruhi oleh Rasa Percaya (H2 terbukti) dan persepsi terhadap kegunaan (H4 terbukti). Ini sesuai dengan hasil penelitian Aren et al. (2013). Minat beli online tidak dipengaruhi secara signifikan oleh persepsi terhadap kemudahan

Tabel 2. Statistik deskriptif variabel penelitian

\begin{tabular}{lccc}
\hline \multicolumn{1}{c}{ Variabel } & Indikator & Rata-rata & $\begin{array}{c}\text { Standar } \\
\text { deviasi }\end{array}$ \\
\hline Rasa & TR1 & 6,42 & 0,912 \\
percaya & TR2 & 6,04 & 1,172 \\
& TR3 & 6,23 & 0,973 \\
& TR4 & 6,08 & 1,000 \\
Informasi & WI1 & 6,25 & 0,998 \\
pada situs & WI2 & 6,15 & 1,088 \\
& WI3 & 5,70 & 1,245 \\
Kemudahan & EOU1 & 5,76 & 1,197 \\
penggunaan & EOU2 & 5,83 & 1,209 \\
& EOU3 & 5,49 & 1,311 \\
& EOU4 & 6,00 & 1.070 \\
Persepsi & PU1 & 4,85 & 1,485 \\
pada & PU2 & 5,20 & 1,382 \\
kegunaan & PU3 & 5,59 & 1,163 \\
situs & OPI1 & 5,25 & 1,283 \\
Minat beli & OPI2 & 5,05 & 1,284 \\
secara & OPI3 & 5,07 & 1,189 \\
online & OPI4 & 5,28 & 1,399 \\
\hline
\end{tabular}

Tabel 3. Variabel laten dan indikatornya

\begin{tabular}{lccccc}
\hline & TR & OPI & WI & EOU & PU \\
\hline TR1 & 0,74 & & & & \\
TR2 & 0,75 & & & & \\
TR3 & 0,83 & & & & \\
OPI1 & & 0,79 & & & \\
OPI2 & & 0,89 & & & \\
OPI3 & & 0,83 & & & \\
WI1 & & & 0,72 & & \\
WI2 & & & 0,68 & & \\
EOU1 & & & & 0,79 & \\
EOU3 & & & & 0,74 & \\
EOU4 & & & & 0,82 & \\
PU2 & & & & & 0,79 \\
PU3 & & & & & 0,86 \\
\hline
\end{tabular}

penggunaan (H3 ditolak), dan ini tidak sejalan dengan hasil penelitian Aren et al. (2013).

Rasa percaya timbul dari informasi yang disajikan pada situs. Rasa percaya dan persepsi terhadap kegunaan situs dalam membantu kehidupan menjadi dua faktor yang menentukan minat beli pelanggan. Kemudahan menggunakan situs dalam berbelanja tidak memengaruhi minat beli online diduga karena semua responden sudah pernah berbelanja online sehingga sudah dapat memahami dengan baik cara berbelanja online. Di samping itu, prosedur dan tata cara berbelanja online pada dasarnya hampir sama.

Jadi, informasi yang disajikan pada situs dapat meningkatkan rasa percaya pengunjung dan menjadi faktorpentingdalammenentukankeberhasilanpenjualan melalui situs. Informasi yang akurat mengenai produk serta informasi mengenai cara melakukan transaksi menjadi dua informasi utama yang harus disampaikan dengan memadai dalam situs. Kedua informasi ini dapat meningkatkan rasa percaya pengunjung dan pada akhirnya dapat meningkatkan minat beli. Sementara itu, persepsi terhadap kegunaan situs dalam hal memudahkan berbelanja dan membuat hidup makin mudah akan makin meningkat jika produsen memiliki komitmen yang tinggi dalam memenuhi kewajibannya terhadap para pembeli online, juga dipengaruhi faktor eksternal seperti perkembangan teknologi informasi, infrastruktur pendukung, perubahan gaya hidup, dan tingkat melek internet.

Interpretasi riil dari hasil penelitian di atas diwujudkan dalam merancang situs yang dapat meningkatkan minat beli pengunjung. Ini dilakukan pada tahap penelitian selanjutnya, yaitu merancang situs untuk sebuah perusahaan yang menawarkan pangan olahan organik. Situs pada dasarnya bertujuan menyampaikan informasi kepada pengunjung. Artinya, dua indikator dari variabel independen informasi pada situs, yaitu informasi yang akurat mengenai produk serta informasi mengenai cara melakukan transaksi, harus dapat dipaparkan dengan baik pada situs. Terkait dengan situs dari produsen makanan olahan organik sebagai objek studi maka informasi mengenai produk yang sebaiknya tercantum dalam situs antara lain adalah sebagai berikut:

a. Bahan baku dan perangkat produksi yang digunakan

b. Keunggulan produk relatif terhadap produk substitusinya

c. Testimoni dari konsumen yang pernah membeli 
online

d. Sertifikasi produk dan/atau penghargaan yang diterima

e. Artikel-artikel kesehatan dari sumber yang kredibel

f. Harga produk

g. Nutrisi yang terkandung dalam produk

h. Manfaat yang diperoleh setelah mengkonsumsi produk

Informasi mengenai pangan organik, jika ditambah dengan informasi mengenai norma deskriptif yang berlaku di masyarakat akan mampu meningkatkan jumlah pembelian online. Penelitian yang dilakukan oleh Charalambides et al. (2015) membuktikan dalam eksperimennya bahwa penambahan informasi mengenai norma deskriptif mampu menjadi insentif bagi perilaku pembelian online untuk produk ramah lingkungan. Sementara itu, pengaruh positif dari norma terhadap perilaku ekologis Generasi Y di Indonesia telah dibuktikan dalam studi yang dilakukan oleh Suryandari et al. (2016). Informasi yang akurat mengenai manfaat produk perlu ditekankan karena dapat meningkatkan minat beli berdasarkan penelitian terdahulu yang dilakukan oleh Firmanzah dan Sari (2009) serta Putra dan Suryani (2016). Di samping

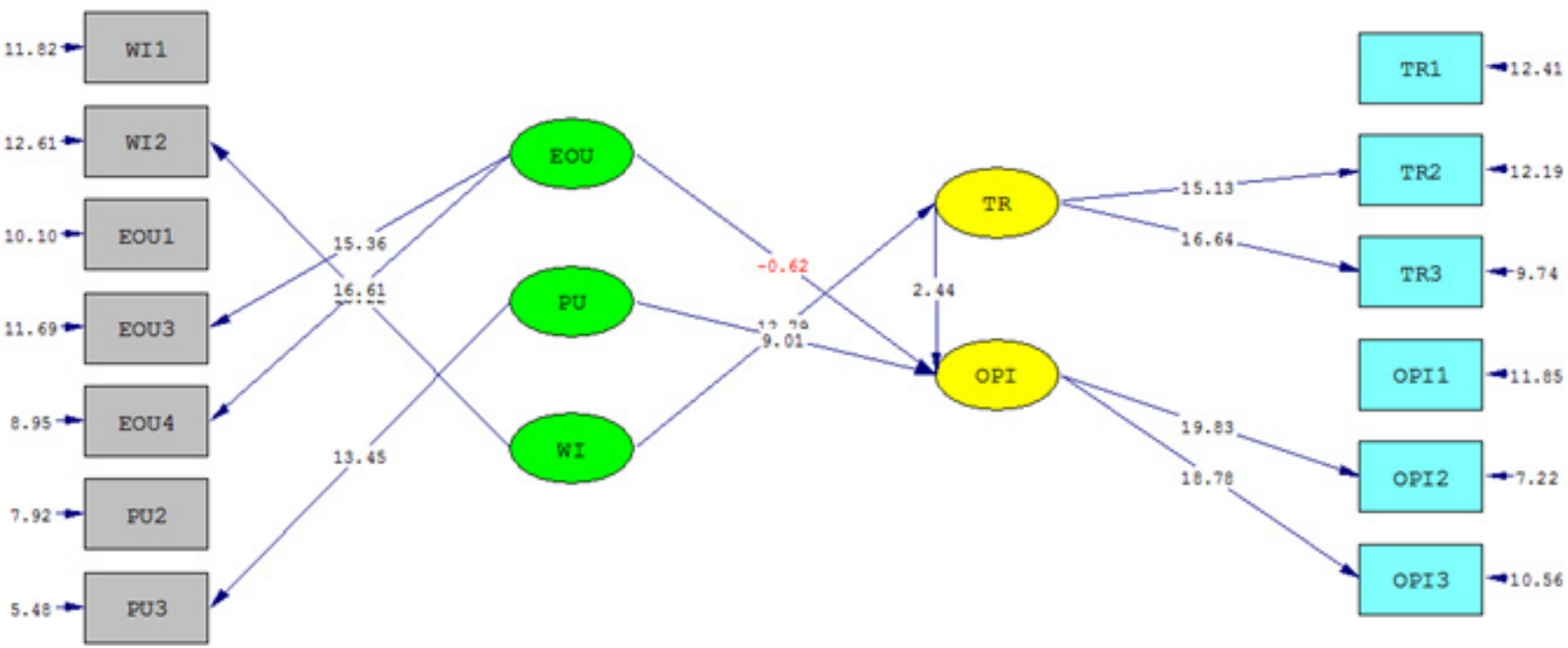

Chi-Square $=113,38$, df $=58, P=$ value $=0,00002$, RKSEA $=0,046$

Gambar 3. Uji signifikansi (t-test) model penelitian

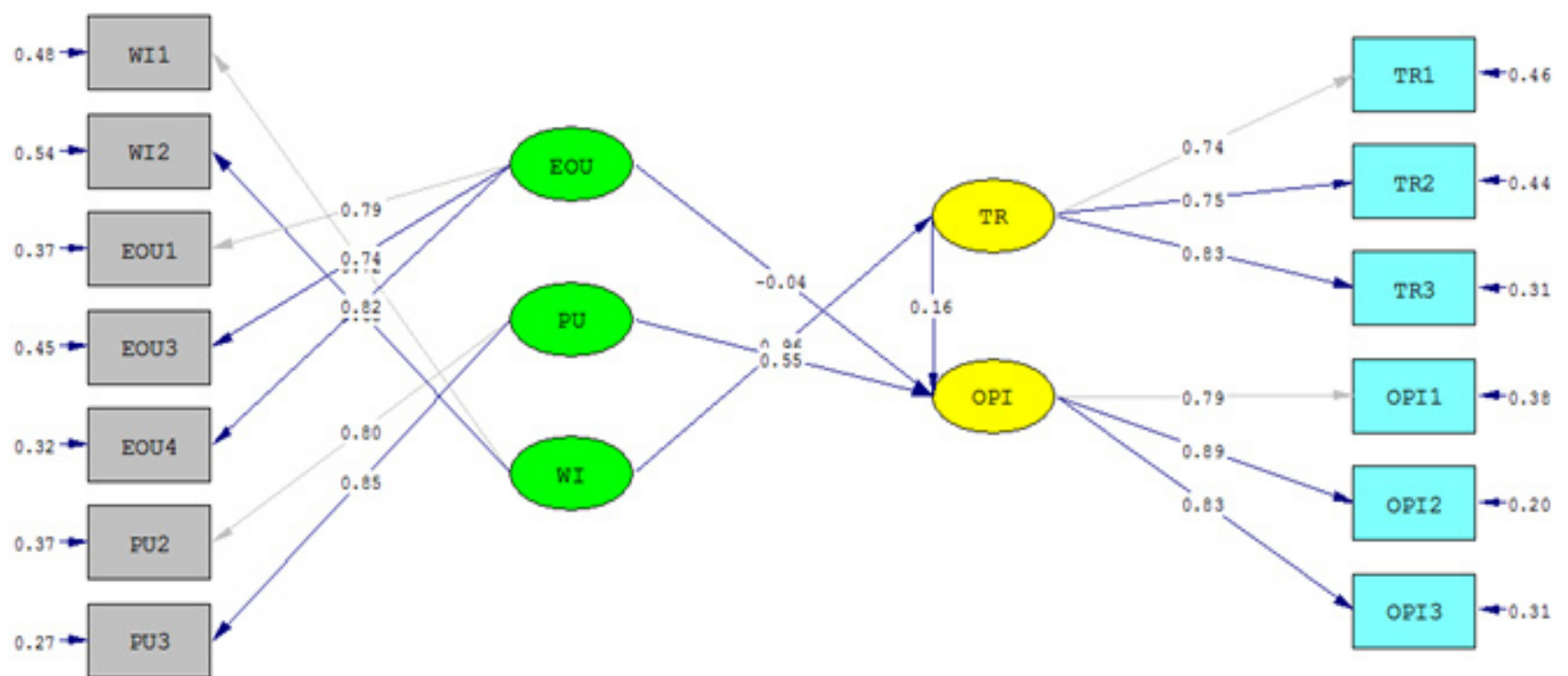

Chi-Square $=113,38$, df $=58, \mathrm{P}=$ value $=0,00002$, RMSEA $=0.046$

Gambar 4. Standardized loading factor model penelitian 
itu, produsen sebaiknya secara berkala melakukan pembaharuan terhadap informasi yang ditampilkan pada situs agar tetap akurat.

Layanan yang diberikan pada pelanggan online harus benar-benar dijaga, salah satunya dengan menyampaikan produk kepada pembeli yang sesuai dengan informasi di situs. Misalnya produk yang ditawarkan benar-benar memiliki kualitas dan kandungan nutrisi yang sama dengan yang disampaikan pada situs. Hal ini penting karena jika pelanggan online mengalami kekecewaan terhadap produk yang dibelinya, maka pelanggan tersebut akan langsung berhenti berbelanja online. Kaur dan Sukla (2016) menyatakan bahwa faktor situasional menjadi pemicu awal untuk berbelanja online, misalnya melahirkan, hambatan kesehatan, dan lain-lain. Ketika faktor ini sudah tidak ada, atau pelanggan mengalami masalah dengan layanan yang diberikan, maka para pelanggan tersebut cenderung akan berhenti berbelanja online.

Di samping itu, berdasarkan profil para pembeli online, disarankan agar produsen tersebut juga melakukan promosi lewat berbagai media sosial dengan tautan yang mengarah kepada situs web, untuk menjaring para pembeli potensial yang aktif menggunakan media sosial dan sekaligus memberikan informasi yang memadai mengenai produk yang ditawarkan. Tipe media sosial yang sesuai untuk menyampaikan iklan yang berfokus pada penyampaian konten informasi adalah blog dan mikroblog. Zunaidi (2016) dalam penelitiannya menemukan bahwa kualitas informasi dari iklan di media sosial tipe blog dan mikroblog mampu memengaruhi minat beli.

\section{Implikasi Manajerial}

Implikasi terapan dari penelitian ini adalah informasi yang akurat dan memadai pada situs menjadi kunci dalam meningkatkan kepercayaan pengunjung terhadap produk yang ditawarkan, dan akhirnya meningkatkan minat beli. Oleh karena itu, para produsen produk olahan organik disarankan untuk menampilkan beberapa informasi berikut pada situs, diantaranya adalah bahan baku dan perangkat produksi yang digunakan, keunggulan produk relatif terhadap produk substitusinya, testimoni dari konsumen yang pernah membeli online, sertifikasi produk dan/ atau penghargaan yang diterima, dan artikel-artikel kesehatan dari sumber yang kredibel. Di samping itu, disarankan pula untuk melakukan peninjauan secara berkala terhadap informasi yang ditampilkan. Implikasi teoritis dari penelitian ini adalah, penelitian ini memperkaya technology acceptance model dalam konteks pemasaran online, yaitu dengan mengajukan anteseden dari rasa percaya (informasi yang disampaikan pada situs).

\section{KESIMPULAN DAN SARAN}

\section{Kesimpulan}

Produk organik jika dikembangkan dapat menjadi sumber keunggulan kompetitif Indonesia. Di samping itu, sistem pertanian organik menguntungkan bagi perbaikan dan peningkatan kualitas lingkungan di Indonesia. Pengembangan pasar produk organik di dalam negeri yang saat ini masih rendah dapat menjadi salah satu langkah awal yang dapat dilakukan. Karakteristik produk organik yaitu kurangnya manfaat yang segera dan harga yang relatif tinggi membuat posisi tawar lebih rendah relatif terhadap produk substitusinya. Pemasaran menjadi kunci dalam meningkatkan konsumsi produk organik di Indonesia. Mengingat keterbatasan sumber daya finansial pada sebagian besar pelaku bisnis produk organik di Indonesia, membuat pemasaran online menjadi strategi yang tepat karena membutuhkan biaya investasi yang relatif rendah, mudah digunakan, cakupan jaringan yang luas, penyebaran dan pengumpulan informasi cepat serta mudah mencari mitra bisnis potensial. Namun demikian, perancangan pemasaran online harus direncanakan dengan baik sehingga dapat mendukung peningkatan penjualan.

Pemasaran online melalui situs adalah sangat tepat mengingat karakteristik produk organik yang membutuhkan pemaparan informasi yang rinci dan intensif pada para pelanggan potensialnya. Hasil penelitian ini menunjukkan bahwa faktor-faktor yang memengaruhi minat beli online adalah rasa percaya dan persepsi terhadap kegunaan. Hasil penelitian ini sejalan dengan hasil penelitian yang dilakukan oleh Aren et al. (2013), Andromeda (2015) serta Wu dan Ke (2015). Sementara itu, rasa percaya dipengaruhi oleh informasi yang disajikan oleh situs, sejalan dengan hasil penelitian Ponte et al. (2015). Persepsi terhadap kemudahan penggunaan tidak memengaruhi minat beli pengunjung situs, dan ini tidak sejalan dengan hasil 
penelitian Aren et al. (2013), Andromeda (2015) serta Wu dan Ke (2015).

\section{Saran}

Saran yang diberikan untuk penelitian selanjutnya adalah menguji model ini pada konteks media sosial. Data menunjukkan bahwa 63 juta penduduk Indonesia adalah pengguna internet, dan $95 \%$ dari pengguna tersebut menggunakannya untuk mengakses jejaring sosial. Sementara itu, jejaring sosial yang paling banyak diakses adalah Facebook dan Twitter (Kominfo, 2017). Oleh karena itu, pemasaran pangan organik melalui kedua media tersebut sangat potensial untuk mengembangkan pasar, serta meningkatkan manfaat dari kedua media tersebut untuk kemajuan produksi lokal.

\section{DAFTAR PUSTAKA}

Andromeda K. 2015. Analisis pengaruh kepercayaan, kemudahan, dan keragaman produk pakaian via online terhadap keputusan pembelian secara online (Studi kasus pada mahasiswa belanja online pada FEB Universitas Muhammadiyah Surakarta) [skripsi]. Surakarta: Fakultas Ekonomi \& Bisnis Program Studi Manajemen Universitas Muhammadiyah Surakarta.

Aren S, Güzel M, Kabadayi E, Alpkan L. 2013. Factor affecting repurchase intention to shop at the same website. Precedia Social and Behavioral Sciences 99:536-544. https://doi.org/10.1016/j. sbspro.2013.10.523.

CharalambidesL,HiltonDJ, WaroquierL.2015.Nudging sustainable consumption: the use of descriptive norms to promote a minority behavior in a realistic online shopping environment. Journal of Environmental Psychology 43: 166-174. https://doi.org/10.1016/j.jenvp.2015.06.008.

Creswell J. 2016. Research Design Pendekatan Metode Kualitatif, Kuantitatif, dan Campuran Edisi 4 (terj). Yogyakarta: Pustaka Belajar.

Davis FD. 1989. Perceived ease of use, Perceived Usefulness, and user acceptance of information technology. MIS Quarterly (13)3: 319. https:// doi.org/10.2307/249008.

Erkan I, Evans C. 2016. The influence of eWOM in social media on consumers' purchase intentions: an extended approach to information adoption. Computers in Human Behavior 61(1): 47-55. https://doi.org/10.1016/j.chb.2016.03.003.

Firmanzah, Sari H. 2009. Intention to buy green products: the impact of consumer education on perceived benefit, economic accessibility and environmental concern. Di dalam: Proceeding of International Conference on KnowledgeBased Economy \& Global Management; Taiwan, 22 - 23 October 2009. Taiwan: Southern Taiwan University: hlm. 13-25.

Gefen D. 2003. TAM or just plain habit: A look at experienced online shoppers. Journal of End User Computing (15)3: 1-13.

Gefen D, Karahanna E, Straub DW. 2003. Trust and TAM in online shopping: An integrated model. MIS Quarterly (27)1: 51-90. https://doi. org/10.4018/joeuc.2003070101.

Hair JF, Black WC, Babin BJ, Anderson RE. 2010. Multivariate Data Analysis: A Global Perspective 7th Ed. Upper Saddle River. New Jersey: Pearson Education, Inc.

Handriana E. 2014. Pertumbuhan Pangan Organik Nasional Hanya 5 Persen. http://www. suaramerdeka.com. [23 Juli 2016].

Hong-You H, John J, John JD, Chung YK. 2016. Temporal effects of information from social networks on online behavior. Internet Research 26(1): 213-235. https://doi.org/10.1108/IntR03-2014-0084.

Idaman N, Yuliarti LN, Retnaningsih. 2012. Sikap konsumen terhadap beras organik. Jurnal Manajemen \& Agribisnis (9) 2: 117-126.

IFOAM. 2015. Global organic market at 72 billion US dollars with 43 million hectares of organic agricultural land worldwide. https://www.ifoam. bio/en/news/2015 [15 Februari 2015].

Kaur H, Shukla RK. 2016. Consumer's attitude towards online grocery shopping in Delhi City. International Journal of Multidisciplinary Approach and Studies 3(2):29-41.

Kaplan AM, Detlef S, Michael H. 2007. Factors influencing the adoption of mass customization: The impact of base category consumption frequency and need satisfaction. Journal of Product Innovation Management 24: 101-116. https://doi.org/10.1111/j.1540-5885.2007. 00237.x.

Khare A. 2016. Consumer shopping styles and online shopping: an empirical study of Indian consumers. Journal of Global Marketing 29(1):40-53. https://doi.org/10.1080/08911762. 2015.1122137. 
Kominfo. 2017. Kominfo: pengguna internet di Indonesia 63 Juta orang. https://kominfo.go.id. [15 Februari 2017].

Muzayanah FN, Suroso AI, Najib M. 2015. Faktorfaktor yang memengaruhi resistensi pembelian pangan organic dan proses pendidikan konsumen. Jurnal Manajemen \& Agribisnis 12(3):163-173. https://doi.org/10.17358/JMA.12.3.163.

Petra KK. 2016. Generation Y attitudes towards shopping: a comparison of the Czech Republic and Slovakia. Journal of Competitiveness 8(1): 38-54. https://doi.org/10.7441/joc.2016.01.03.

Putra IPASS, Suryani A. 2016. Peran green trust dalam memediasi pengaruh green perceived value terhadap green purchase behavior. Jurnal Manajemen, Strategi Bisnis dan Kewirausahaan 10 (1):42-51.

Ponte EB, Trujillo EC, Rodríguez TE. 2015. Influence of trust and perceived value on the intention to purchase travel online: Integrating the effects of assurance on trust antecedents. Tourism Management 47: 286-302. https://doi. org/10.1016/j.tourman.2014.10.009.

Sari H, Firmanzah. 2011. Segmentation for environmental friendly products and its implication to product design: Indonesian context. Di dalam: Proceeding of 2011 IEEE International Summer Conference of Asia Pacific; Dalian, 1012 July 2011. Tiongkok: Business Innovation and Technology Management (APBITM), hlm. 168-171.
Solomon MR. 2007. Consumer behavior: Buying, heaving and being. Singapura: Pearson Prentice Hall.

Suryandari NKD, Suprapti NWS, Sukaatmadja IPG. 2016. Aplikasi Theory of Planned Behavior dalam menjelaskan perilaku ekologis generasi Y di kota Denpasar. Jurnal Manajemen, Strategi Bisnis dan Kewirausahaan 10 (1):31-41.

Venkatesh V. 2000. Determinants of perceived ease of use: Integrating control, intrinsic motivation, and emotion into technology acceptance model. Information Systems Research (11)4: 342-365. https://doi.org/10.1287/isre.11.4.342.11872.

Wijanto SH. 2008. Structural Equation Modelling dengan Lisrel 8.8: Konsep \& Tutorial. Jakarta: Graha Ilmu.

Wu W, Ke C. 2015. An online shopping behavior model integrating personality traits, perceived risk, and technology acceptance. Social Behavior And Personality 43(1):85-98.

Zikmund WG. 2000. Business Reseach Methods (6th ed.). The Dryden Press Harcourt College Publishers.

Zunaidi RA. 2016. Pengaruh tipe media sosial terhadap information acceptance model(IACM) pada iklan produk UKM industri sandang melalui media sosial [tesis]. Bandung: Program Studi Teknik dan Manajemen Industri Fakultas Teknologi Industri Institut Teknologi Bandung. 